\title{
Perancangan Aplikasi Multimedia Untuk Pembelajaran Gerbang Logika Menggunakan Augmented Reality
}

\author{
Rosdelima Hutahaean ${ }^{1)}$, R.Rizal Isnanto ${ }^{2)}$, Kurniawan Teguh Martono ${ }^{3)}$ \\ Program Studi Sistem Komputer, Fakultas Teknik, Universitas Diponegoro \\ Jl. Prof. Sudharto, Tembalang, Semarang, Indonesia \\ Email: ros.hutahaean@gmail.com
}

\begin{abstract}
As the rapid development of technology is also growing media that is used as a method of learning in education. One of them to learning logic states, in addition to reading the book at this time there has a new learning method that is more pronounced in 3 dimensions to increase understanding in learning the logic gates using Augmented Reality.

Steps design multimedia for learning the logic gates begins with a literature study, data collection, analysis and system design and then implementation and testing the system. Testing methods using a black-box, which includes testing functionality testing camera angles and distances to the markers as well as testing the light intensity.

The result of the design this application shows that for angle of $30^{\circ}$ with a distance of 30 $\mathrm{cm}-40 \mathrm{~cm}$, angle of $45^{\circ}$ with a distance of $40 \mathrm{~cm}-$ $70 \mathrm{~cm}$ and angle of $60^{\circ}$ with a distance of $50 \mathrm{~cm}-$ $90 \mathrm{~cm}$ and light intensity $4 \mathrm{~lx}-19 \mathrm{~lx}$ is a good composition can display the object 3 dimensions.
\end{abstract}

Kata Kunci: Logic Gates, Augmented Reality, ARToolkit, 3D Studio Max.

\subsection{Latar Belakang}

\section{PENDAHULUAN}

Dalam belajar gerbang logika selain membaca buku telah tersedia media yang bersifat lebih multimedia yang lebih menarik untuk dipelajari. Pada saat ini telah ada satu metode pembelajaran terbaru yang lebih nyata secara 3 dimensi dalam pembelajaran gerbang logika menggunakan Augmented Reality.

Augmented Reality merupakan penggabungan antara dua dunia, yaitu dunia maya ke dunia nyata, dalam kata lain benda dalam dunia maya dapat ditampilkan ke dunia nyata. Aplikasi Augmented Reality pada umumnya dikembangkan pada PC Desktop dan banyak sekali metode yang digunakan untuk Augmented Reality, antara lain adalah metode marker based tracking.

Metode pelacakan berbasis penanda (marker based tracking) adalah metode yang memproses objek dua dimensi, objek tiga dimensi, teks, video maupun suara menggunakan komputer dan webcam lalu ditampilkan dalam layar maupun peralatan display khusus melalui pengenalan sebuah penanda (marker). Dimana program akan membaca objek dari sebuah penanda gambar, dan dari gambar tersebut akan ditampilkan objek yang bergerak atau output yang sudah ada pada data sebelumnya.

\subsection{Rumusan Masalah}

Berdasarkan latar belakang yang telah dijelaskan diatas, dapat dibuat suatu rumusan masalah sebagai berikut:

"Bagaimana merancang suatu aplikasi multimedia untuk pembelajaran gerbang logika menggunakan Augmented Reality?"

\subsection{Batasan Masalah}

Untuk menghindari pembahasan yang meluas, maka dalam Tugas Akhir ini ditetapkan batasan-batasan masalah sebagai berikut:

1. Pengguna aplikasi yaitu peserta didik di bidang komputer maupun bidang lain yang ingin mempelajarinya.

2. Materi yang disampaikan pada aplikasi berupa pengenalan gerbang logika, tabel kebenaran gerbang logika, pengenalan Half-Adder serta Full-Adder.

3. Aplikasi dirancang untuk pengguna PC Desktop, dimana terdapat webcam yang mengarah ke marker dalam suatu buku dan layar desktop menampilkan aplikasi Augmented Reality.

4. Keluaran yang dihasilkan adalah model 3 dimensi menggunakan media marker based yang memanfaatkan teknologi Augmented Reality.

\subsection{Tujuan Tugas Akhir}

Tujuan dalam tugas akhir ini adalah sebagai berikut:

1. Merancang aplikasi pembelajaran gerbang logika yang menggunakan teknologi Augmented Reality sebagai media pembelajaran. 
2. Menampilkan gambaran 3 dimensi pengenalan gerbang logika, tabel kebenaran gerbang logika, Half-Adder serta FullAdder.

3. Dapat memberikan pengalaman baru dalam belajar dengan teknologi Augmented Reality.

\subsection{Definisi Multimedia}

\section{DASAR TEORI}

Multimedia terdiri dari dua kata yaitu multi dan media, dimana multi berarti banyak, majemuk, dan beraneka raga, sedangkan media berarti suatu alat perantara untuk penyampaian sesuatu.

Multimedia juga merupakan kombinasi teks, grafik, suara, animasi dan video yang disampaikan dengan komputer atau peralatan manipulasi elektronik dan digital yang lain ${ }^{[8]}$.

\subsection{Gerbang Logika}

Gerbang logika adalah blok bangunan dasar untuk membentuk rangkaian elektronika digital, yang digambarkan dengan simbolsimbol tertentu yang telah ditetapkan. Sebuah gerbang logika memiliki beberapa masukan tetapi hanya memiliki satu keluaran.

Untuk menunjukkan hubungan antara masukan dan keluaran untai logika dapat digunakan suatu tabel kebenaran.

\section{Gerbang NOT}

Gerbang NOT disebut inverter karena berfungsi membalik logika keluaran terhadap logika masukan.

\section{Gerbang AND}

Keluaran gerbang AND akan berlogika 1 jika semua masukannya 1 .

3. Gerbang OR

Keluaran gerbang OR akan berlogika 1 jika salah satu masukannya 1 .

4. Gerbang NAND

Gerbang NAND merupakan gabungan dari gerbang AND dan NOT.

\section{Gerbang NOR}

Gerbang NOR merupakan gabungan dari gerbang OR dan NOT.

\section{Gerbang EX-OR}

Gerbang EX-OR berlogika 1 jika logika masukan gerbang ini berbeda, dan berlogika 0 jika logika masukan gerbang ini sama.

7. Gerbang EX-NOR

Gerbang EX-NOR merupakan gabungan dari gerbang EX-OR yang keluarannya diNOT-kan ${ }^{[6]}$.

\section{Half-Adder}

Half-Adder adalah operasi yang membutuhkan dua bilangan masukan sebagai bit dasar dan bit penjumlah, dan dua bilangan keluaran sebagai hasil jumlah (sum) dan simpan $(\text { carry })^{[1]}$.

\section{Full-Adder}

Full-Adder adalah sebuah rangkaian kombinasi yang membentuk jumlah aritmatika dari tiga bit masukan, dimana terdiri dari tiga masukan dan dua keluaran ${ }^{[1]}$.

\subsection{Augmented Reality}

Augmented reality (AR) atau dalam bahasa Indonesia disebut realitas tertambah adalah teknologi yang menggabungkan bendabenda maya dua dimensi dan ataupun tiga dimensi ke dalam sebuah lingkungan nyata lalu memproyeksikan benda-benda maya tersebut dalam waktu nyata.

Komponen yang diperlukan dalam pembuatan dan pengembangan aplikasi augmented reality adalah sebagai berikut:

1. Komputer

Komputer merupakan perangkat yang digunakan untuk mengendalikan semua proses yang akan terjadi dalam sebuah aplikasi.

\section{Head Mounted Display (HMD}

Head Mounted Display

(HMD) merupakan perangkat keras yang digunakan sebagai display atau monitor yang akan menampilkan obyek 3D ataupun informasi yang akan disampaikan oleh sistem.

3. Penanda (Marker)

Marker merupakan gambar (image) dengan warna hitam dan putih dengan bentuk persegi. ${ }^{[7]}$.

Secara umum proses marker dengan menggunakan library Artoolkit adalah sebagai berikut:

1. Kamera menangkap gambar dari dunia nyata secara langsung dan mengirimkannya ke komputer.

2. Perangkat lunak dalam komputer akan mencari Marker pada masing-masing frame video.

3. Jika Marker telah ditemukan, komputer akan memproses secara matematis posisi relatif dari kamera ke kotak hitam yang terdapat pada Marker.

4. Apabila posisi kamera diketahui, objek grafis akan digambar menggunakan informasi tersebut. 
5. Objek ini digambar di atas video yang di dapat dan tampak menempel di atas Marker.

6. Output final akan ditampilkan pada display di monitor. Sehingga ketika pengguna melihat monitor objek akan tampak seolah berada di dunia nyata ${ }^{[3]}$.

\subsection{VRML (Virtual Reality Modeling Language) \\ VRML (Virtual Reality Modeling} Language) adalah sebuah bahasa pemrograman yang diciptakan khusus untuk membuat objekobjek 3D. Objek-objek yang dibuat dengan VRML akan memiliki tiga buah dimensi panjang, lebar, dan kedalaman, sehingga dapat dipandang dari setiap sudut ${ }^{[5]}$.

VRML merupakan sebuah ekstensi file atau sistem file untuk menampilkan gambar objek 3D yang mendukung penggunaan augmented reality.

\subsection{Ds Max Studio}

3D Studio Max adalah sebuah perangkat lunak grafik vektor 3-dimensi dan animasi, ditulis oleh Autodesk Media \& Entertainment (dulunya dikenal sebagai Discreet and Kinetix). Aplikasi ini mempunyai banyak fitur-fitur yang diperlukan dalam pembuatan karya $3 \mathrm{D}^{[2]}$.

\subsection{Adobe Photoshop CS3}

Adobe Photoshop merupakan salah satu perangkat lunak pengolah gambar (digital imaging) yang banyak digunakan dan memberikan kontribusi bagi dunia digital dan $\operatorname{cetak}^{[4]}$.

\subsection{Microsoft Visual Basic 2010}

Microsoft visual basic 2010 merupakan bahasa pemrograman popular, dimana visual basic 2010 bagian dari produk Microsoft Visual Studio 2010 yaitu sistem pembangunan yang komprehensif yang memungkinkan untuk membuat aplikasi untuk Windows, Web, perangkat genggam dan sejumlah lingkungan lainnya ${ }^{[9]}$.

\section{III.ANALISIS DAN PERANCANGAN SISTEM}

\subsection{Gambaran Umum Aplikasi}

Sistem multimedia untuk pembelajaran proses gerbang logika menggunakan augmented reality ini menggunakan web-cam untuk mendapatkan output yang menampilkan modelAR dengan pendeteksian pola marker.

\subsection{Pemodelan Perangkat Lunak}

UML (Unified Modeling Language) adalah bahasa pemodelan visual yang digunakan untuk menentukan, menvisualisasikan, membangun, dan mendokumentasikan komponen-komponen dari sistem perangkat lunak ${ }^{[16]}$.

3.2.1 Diagram Use Case

Diagram use case dari perancangan aplikasi dapat dilihat pada Gambar 1 .

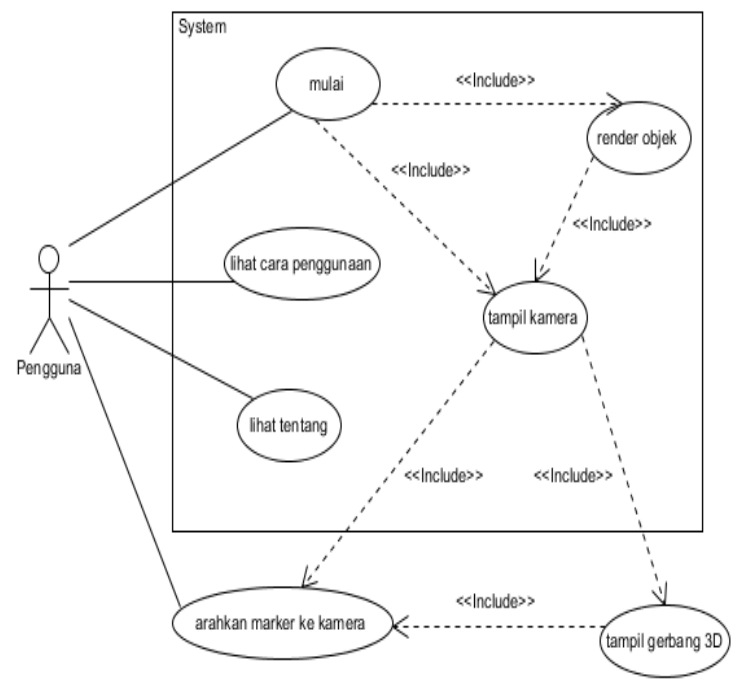

Gambar 1. Diagram Use Case Perancangan Aplikasi

\subsubsection{Diagram Sequence}

1. Diagram sekuens untuk use case mulai Gambar 2 menunjukkan diagram sekuens untuk use case mulai.

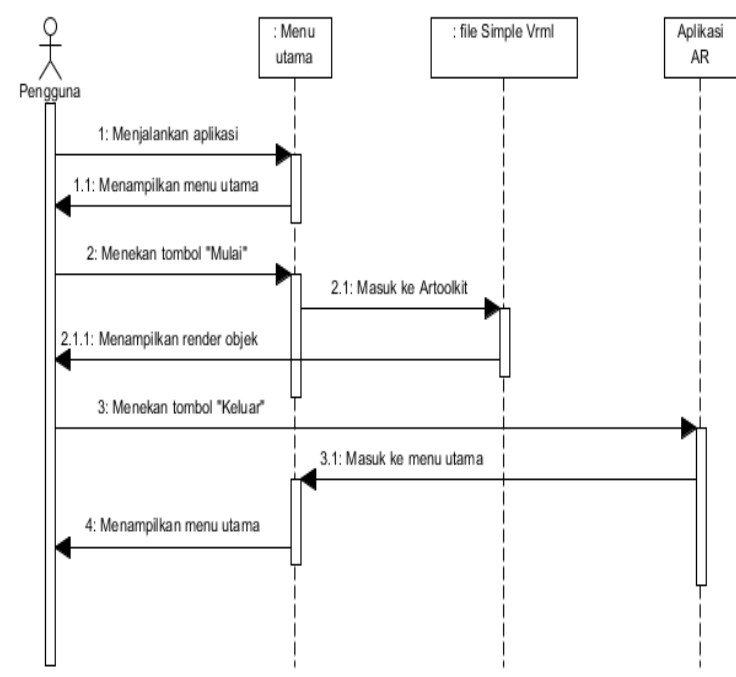

Gambar 2. Diagram Sekuens Use Case Mulai 
2. Diagram sekuens untuk use case lihat cara penggunaan

Gambar 3 menunjukkan diagram sekuens untuk use case lihat cara penggunaan.

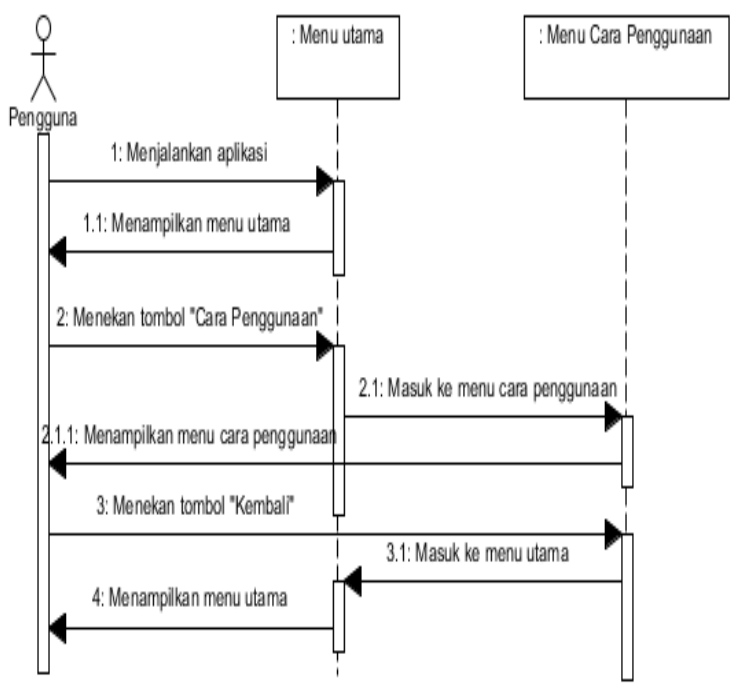

Gambar 3. Diagram Sekuens Use Case Lihat Cara Penggunaan

3. Diagram sekuens untuk use case lihat tentang

Gambar 4 menunjukkan diagram sekuens untuk use case lihat tentang.

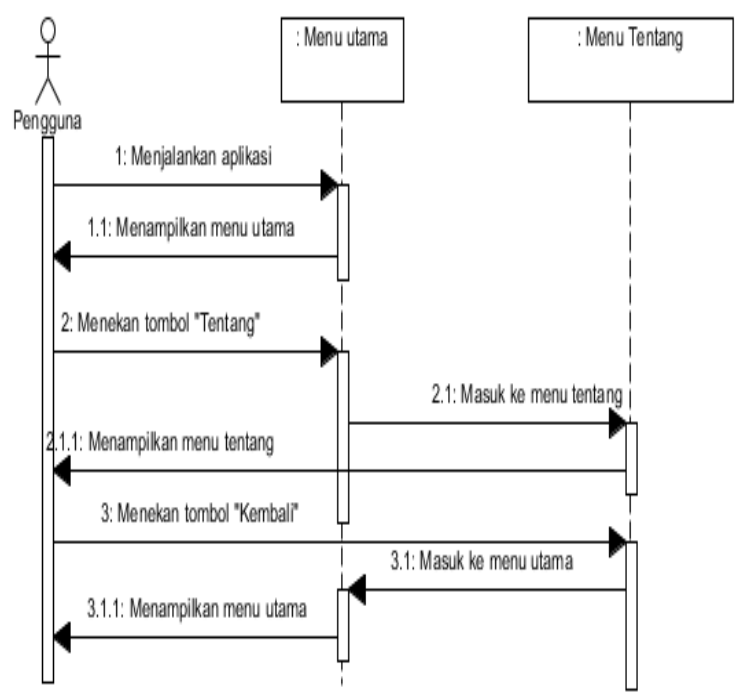

Gambar 4. Diagram Sekuens Use Case Lihat Tentang

4. Diagram sekuens untuk use case arahkan marker ke kamera

Gambar 5 menunjukkan diagram sekuens untuk use case arahkan marker.

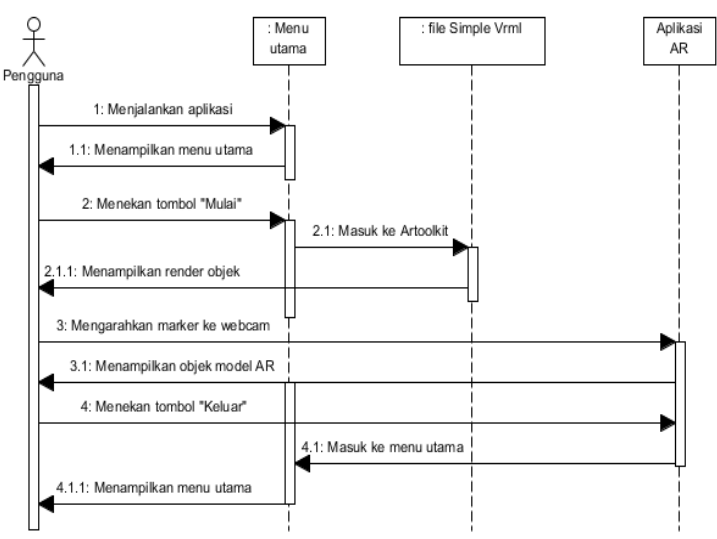

Gambar 5. Diagram Sekuens Use Case Arahkan Marker

\subsubsection{Kelas Diagram}

Diagram kelas dari perancangan ini dapat dilihat pada Gambar 6.

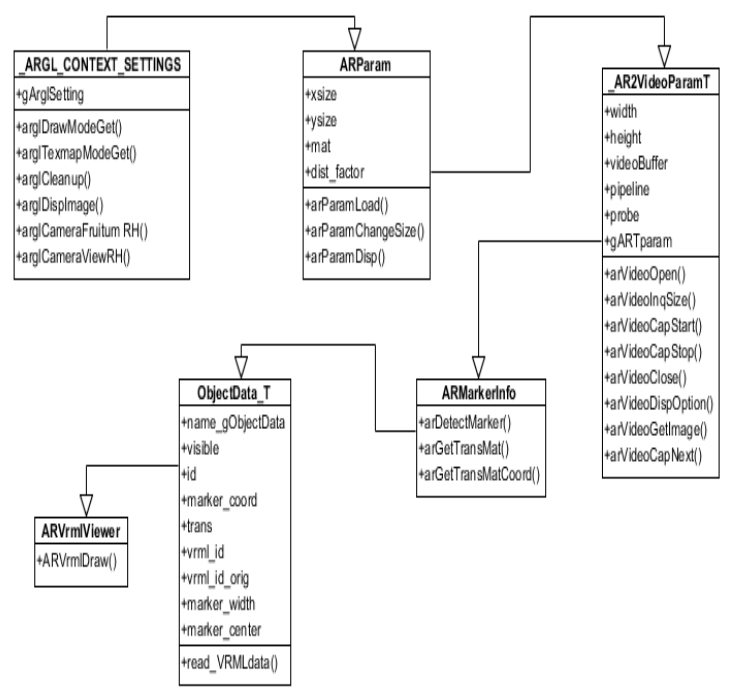

Gambar 6. Diagram Kelas Perancangan Aplikasi

\subsection{Perancangan Sistem}

Tahap perancangan sistem dapat digambarkan dengan aliran kerja (work- flow) pada Gambar 7.

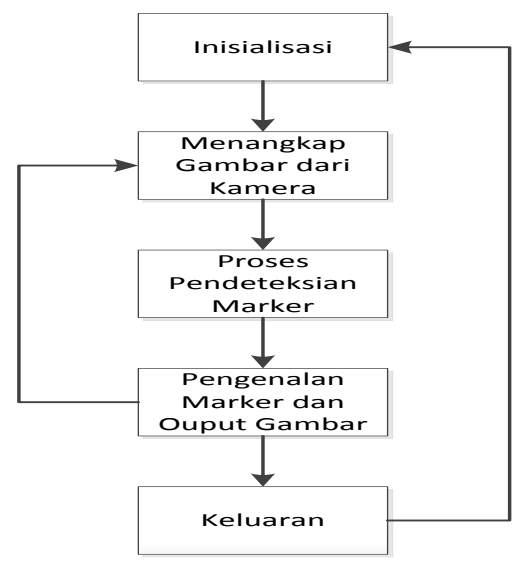

Gambar 7. Aliran Kerja Perancangan Aplikasi 


\subsection{Perancangan Antarmuka}

Tampilan antarmuka diawali tampilan menu utama seperti terlihat pada Gambar 8 .

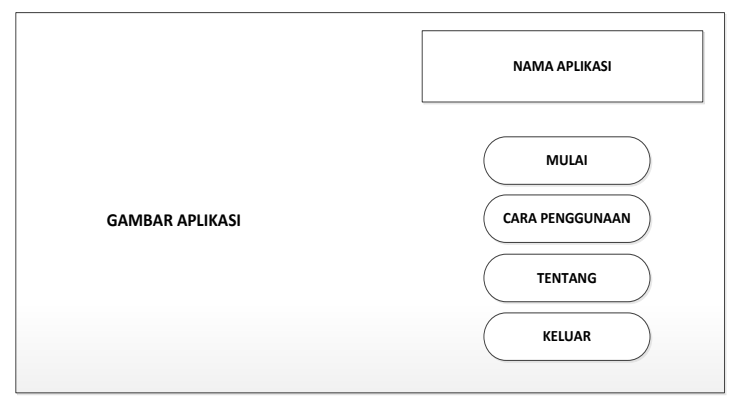

Gambar 8. Rancangan Tampilan Menu Utama

\section{IMPLEMENTASI DAN PENGUJIAN SISTEM}

\subsection{Implementasi Program}

Dalam implementasi program pastikan semua perangkat keras maupun perangkat lunak siap untuk digunakan.

1. Implementasi Visualisasi 3D

Tahap Implementasi Visualisasi 3D dilakukan dengan beberapa tahap yaitu tahap modeling, tahap texturing dan tahap exporting.

Tahap modeling, sebagian besar pembuatan model menggunakan Box, Silinder, Line, Circle, Text dengan Polygon Modeling.

Tahap texturing, model 3 dimensi yang telah dibuat diberikan warna yang berbeda-beda sebagai pengenal setiap objek yang ada pada model tersebut.

Tahap exporting, model diekspor menjadi berkas berekstensi *Wrl dengan cara memilih berkas export, lalu dilakukan save as type dengan tipe VRML97(*Wrl) dan disimpan pada folder ARToolkit/Bin/Wrl.

\section{Implementasi Pembuatan Penanda}

Pembuatan penanda (marker) menggunakan perangkat lunak Adobe Photoshop. Untuk desain dasar penanda dapat memanfaatkan desain Blankpatt yang telah tersedia pada folder patterns di Library ARToolkit, selanjutnya memberi desain tambahan sebagai pembeda setiap penanda (marker).

\section{Implementasi Library ARToolkit}

Setelah pada tahap implementasi visualisasi 3 dimensi menyisipkan berkas ekstensi *Wrl, selanjutnya menambahkan berkas DAT untuk setiap berkas WRL. Berikan nama setiap berkas DAT sesuai nama setiap berkas Wrl.
Tahap selanjutnya implementasi Library ARToolkit dilakukan dengan pemberian skrip pada berkas object_data_vrml.

Setelah langkah implementasi library ARToolkit, dilakukan kompilasi (compiling) simpleVRML untuk mempaketkan library ARToolkit menjadi berkas executable. Kompilasi ini menggunakan Visual $\mathrm{C}++2008$ dengan melakukan konfigurasi pada $\mathrm{C} / \mathrm{C}++$ dan Linker di Properties project SimpleVRML. Setelah itu dilakukan Build (F7) dilanjutkan Debug project (F5).

\section{Implementasi Antarmuka}

Implementasi antarmuka pengguna menggunakan perangkat lunak Visual Basic 2010 dengan Adobe Photoshop.

Tampilan menu UTAMA dapat dilihat pada Gambar 10.

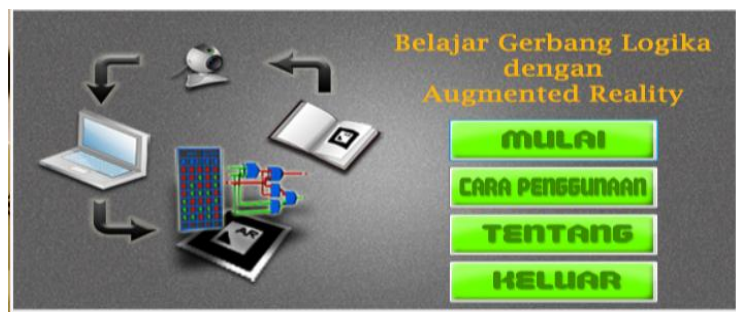

Gambar 9. Desain Tampilan Menu UTAMA Aplikasi

\subsection{Pengujian sistem}

Pengujian sistem dilakukan dengan metode kotak hitam (black-box), dimana pengujian ini menekankan pada pengujian fungsionalitas dari aplikasi pembelajaran gerbang logika menggunakan augmented reality ini.

4.2.1 Hasil Prosentasi Pengujian Sudut dan Jarak Kamera Terhadap Penanda

Tabel 1 menunjukkan prosentase keberhasilan pengujian sudut dan jarak kamera terhadap penanda.

\begin{tabular}{|c|c|c|c|c|c|}
\hline \multirow[b]{2}{*}{ SUDUT } & \multirow{2}{*}{$\begin{array}{l}\text { JARAK } \\
\text { (CM) }\end{array}$} & \multicolumn{2}{|c|}{ KETERANGAN } & \multirow[b]{2}{*}{ PROSENTASE } & \multirow{2}{*}{$\begin{array}{c}\text { HASIL } \\
\text { PROSENTASE }\end{array}$} \\
\hline & & BERHASIL & GAGAL & & \\
\hline \multirow{3}{*}{$30^{\circ}$} & $0-20$ & 0 & 47 & $\frac{0}{47} \times 100 \%$ & $0 \%$ \\
\hline & $30-40$ & 47 & 0 & $\frac{47}{47} \times 100 \%$ & $100 \%$ \\
\hline & $>50$ & 0 & 47 & $\frac{0}{47} \times 100 \%$ & $0 \%$ \\
\hline \multirow{3}{*}{$45^{\circ}$} & $0-30$ & 0 & 47 & $\frac{0}{47} \times 100 \%$ & $0 \%$ \\
\hline & $40-70$ & 47 & 0 & $\frac{47}{47} \times 100 \%$ & $100 \%$ \\
\hline & $>80$ & 0 & 47 & $\frac{0}{47} \times 100 \%$ & $0 \%$ \\
\hline \multirow{3}{*}{$60^{\circ}$} & $0-40$ & 0 & 47 & $\frac{0}{47} \times 100 \%$ & $0 \%$ \\
\hline & $50-90$ & 47 & 0 & $\frac{47}{47} \times 100 \%$ & $100 \%$ \\
\hline & $>120$ & 0 & 47 & $\frac{0}{47} \times 100 \%$ & $0 \%$ \\
\hline $90^{\circ}$ & $0-120$ & 0 & 47 & $\frac{0}{47} \times 100 \%$ & $0 \%$ \\
\hline
\end{tabular}




\subsubsection{Hasil Prosentasi Pengujian Intensitas Cahaya \\ Tabel 2 menunjukkan prosentase} keberhasilan pengujian intensitas cahaya untuk semua penanda yang berjumlah 47 penanda.

\begin{tabular}{|c|c|c|c|c|}
\hline $\begin{array}{c}\text { NNTENSITAS } \\
\text { CAHAYA } \\
\text { MIN-MAX (1x) }\end{array}$ & \multicolumn{2}{|c|}{ KETERANGAN } & \multirow{2}{*}{ PROSENTASE } & $\begin{array}{c}\text { HASI } \\
\text { PROSENTASE }\end{array}$ \\
\cline { 2 - 5 } & GAAGAL & & $0 \%$ \\
\hline $1-4$ & 0 & 47 & $\frac{0}{47} \times 100 \%$ & $100 \%$ \\
\hline $4-12$ & 47 & 0 & $\frac{47}{47} \times 100 \%$ & $100 \%$ \\
\hline $16-19$ & 47 & 0 & $\frac{47}{47} \times 100 \%$ & \\
\hline
\end{tabular}

\subsubsection{Pengujian Tombol Antarmuka}

Tabel 3 menunjukkan hasil pengujian tombol antarmuka dalam aplikasi pembelajaran gerbang logika menggunakan augmented reality.

\begin{tabular}{|c|c|c|c|}
\hline No. & Parameter Pengujian & \multicolumn{1}{|c|}{ Keterangan } & Hasil \\
\hline 1 & Tombol Mulai & $\begin{array}{l}\text { Ketika tombol ditekan, maka } \\
\text { mengarahkan ke halaman } \\
\text { aplikasi dan melakukan } \\
\text { pengaturankamera dilanjutkan } \\
\text { memuat model, lalu aplikasi } \\
\text { siap dijalankan. }\end{array}$ & Benar \\
\hline 2 & Tombol Cara & $\begin{array}{l}\text { Ketika tombol ditekan, maka } \\
\text { akan menampilkan halaman } \\
\text { petunjuk penggunaan aplikasi. }\end{array}$ & Benar \\
\hline 3 & Penggunaan & $\begin{array}{l}\text { Ketika tombol ditekan, maka } \\
\text { akan mengarah ke halaman } \\
\text { informasi aplikasi. }\end{array}$ & Benar \\
\hline 4 & Tombol Keluar & $\begin{array}{l}\text { Ketika tombol ditekan, maka } \\
\text { keluar dariantarmuka aplikasi. }\end{array}$ & Benar \\
\hline 5 & Tombol Berikutnya & $\begin{array}{l}\text { Ketika tombol ditekan, maka } \\
\text { menujukehalaman selanjutrya. }\end{array}$ & Benar \\
\hline 6 & Tombol Kembali & $\begin{array}{l}\text { Ketika tombol ditekan, maka } \\
\text { akan kembali ke halaman } \\
\text { sebelumnya. }\end{array}$ & Benar \\
\hline & & & \\
\hline & & & \\
\hline
\end{tabular}

\subsection{Analisa dan Pembahasan}

Aplikasi pembelajaran gerbang logika menggunakan augmented reality dengan pengaturan sudut kamera, jarak kamera terhadap marker serta intensitas cahaya mempengaruhi dalam menampilkan objek 3 dimensi, untuk sudut $30^{\circ}$ jarak $30 \mathrm{~cm}-40 \mathrm{~cm}$, sudut $45^{\circ}$ jarak $40 \mathrm{~cm}-70 \mathrm{~cm}$ dan sudut $60^{\circ}$ jarak $50 \mathrm{~cm}-90 \mathrm{~cm}$ serta intensitas cahya $4 \mathrm{~lx}$ 19 lx adalah komposisi yang baik untuk menampilkan objek 3 dimensi.

Pada saat menjalankan aplikasi juga terdapat kekurangan yang ditemukan dari aplikasi ini yaitu:

1. Pada saat ditekan tombol MULAI, diperlukan waktu untuk menunggu memuat berkas penanda, ini disebabkan jumlah berkas penanda yang terhitung banyak sehingga membutuhkan waktu untuk memuat seluruh berkas penanda. Gambar 10 menujukkan tampilan saat memuat berkas penanda.

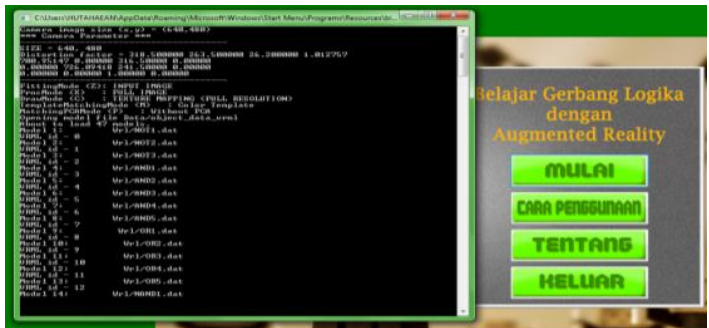

Gambar 10. Hasil Tampilan Memuat Berkas Penanda

2. Aplikasi sering salah dalam membaca arah objek sehingga objek 3 dimensi yang tampil terbalik, hal ini disebabkan proses tracking yang sulit dilakukan penanda dikarenakan pola bagian atas dan bagian bawah penanda yang memiliki kemiripan. Gambar 11 menunjukkan tampilan saat objek terbalik.

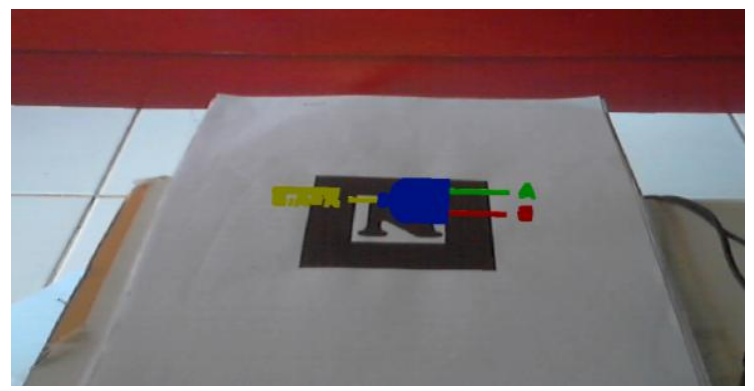

Gambar 11. Hasil Tampilan Saat Objek Terbalik

3. Aplikasi sering salah dalam membaca penanda sehingga penanda menampilkan objek 3 dimensi tidak sesuai dengan keluaran objek yang seharusnya, ini disebabkan pola penanda memiliki kemiripan dengan pola penanda lainnya. Gambar 12 menunjukkan tampilan saat salah dalam pembacaan keluaran objek, dimana penanda gerbang logika NAND masukan $(0,1)$ menampilkan hasil untuk gerbang logika NAND masukan $(0,0)$.

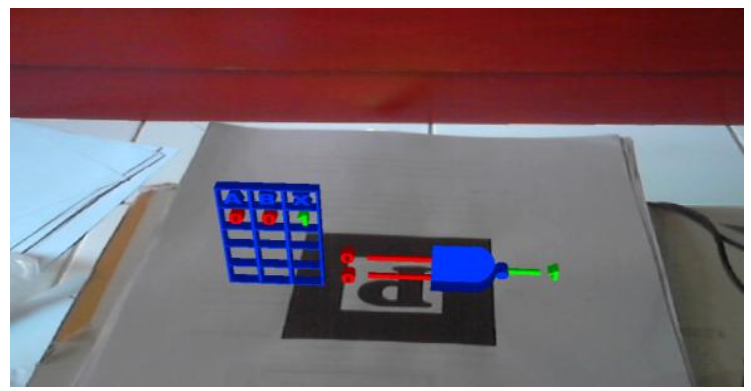

Gambar 12. Hasil Tampilan Saat Salah dalam Pembacaan Penanda 


\subsection{Kesimpulan}

\section{PENUTUP}

1. Teknologi Augmented reality dapat diimplementasikan sebagai media pembelajaran gerbang logika menggunakan Augemented reality.

2. Aplikasi ini dapat menampilkan gambar 3 dimensi dalam pengenalan gerbang logika, tabel kebenaran gerbang logika, Half-Adder dan Full-Adder.

3. Berdasarkan hasil pengujian menggunakan metode Black-Box, pengaturan sudut kamera, jarak kamera terhadap marker mempengaruhi dalam menampilkan objek 3 dimensi. Hal ini ditunjukkan dengan hasil prosentase $100 \%$ pada sudut $30^{\circ}$ jarak 30 $\mathrm{cm}-40 \mathrm{~cm}$, sudut $45^{0}$ jarak $40 \mathrm{~cm}-70 \mathrm{~cm}$ dan sudut $60^{\circ}$ jarak $50 \mathrm{~cm}-90 \mathrm{~cm}$ adalah komposisi yang baik dalam menampilkan objek 3 dimensi.

4. Pengaturan intensitas cahaya mempengaruhi dalam menampilkan objek 3 dimensi. Hal ini ditunjukkan pada cahaya 4 lx - 9 lx dapat menampilkan objek 3 dimensi dengan hasil prosentase $100 \%$.

5. Tombol-tombol navigator yang terdapat pada antarmuka aplikasi berfungsi dengan baik.

6. Aplikasi dalam pembacaan penanda masih mengalami kesalahan disebabkan bentuk dan pola penanda yang memiliki kemiripan dan pengaruh intensitas cahaya.

\subsection{Saran}

1. Perlu dilakukan penelitian lanjutan untuk pengembangan aplikasi dengan melakukan pengembangan terhadap pembuatan model 3 dimensi yang lebih menarik dan lebih interaktif.
2. Penelitian berikutnya dapat dilakukan dengan menambah materi yang lebih banyak dan lengkap mengenai materi gerbang logika.

\section{DAFTAR PUSTAKA}

[1] Godse, A.P., Digital Electronics and Logic Design, Technical Publications, 2009.

[2] Hendratman, Hendi dan Robby, The Magic of 3D Studio Max, Informatika Bandung, 2008.

[3] Hohl, L. dan Quack, T., Markeless 3D Augmented Reality Computer Vision ETH, 2003.

[4] Komputer, Wahana, Teknik Mengolah Foto Digital dengan Adobe Photoshop CS3, Penerbit PT Elex Media Komputindo, Jakarta, 2007.

[5] Kurniadi, Adi, Membuat Dunia 3D dengan VRML, Penerbit PT Elex Media Komputindo, Jakarta, 1999.

[6] Kurniawan, Freddy, Sistem Digital Konsep dan Aplikasi, Penerbit Gava Media, Yogyakarta, 2005.

[7] Siltanen, Sanni, Theory and Applications of Marker-based Augmented Reality, VTT Technical Research Centre of Finland, 2012.

[8] Vaughan. T., Multimedia: Making It Work. Edisi ke-6, McGraw-Hill Companies, New York, 2004.

[9] Willis, Newsome, Beginning Microsoft Visual Basic 2010, Wiley Publishing Inc, USA, 2010. 